Journal of Primary Education
$9(3)(2020): 286-294$
UNNES
https://journal.unnes.ac.id/sju/index.php/jpe

\title{
Mathematics Creative Thinking Skill Reviewed by Students' Metacognitions on Creative Problem Solving Learning Model Implementation
}

\author{
Khoirida Hardini Kurniani $^{1 凶}$, Dwijanto Dwijanto ${ }^{2}$, Nur Karomah Dwidayati ${ }^{2}$
}

DOI: https://doi.org/10.15294/jpe.v9i3.39214

${ }^{1}$ Universitas Muhammadiyah Surakarta, Indonesia

2. Pascasarjana, Universitas Negeri Semarang, Indonesia

\begin{tabular}{l}
\hline Article Info \\
\hline History Articles \\
Received: \\
22 February 2020 \\
Accepted: \\
26 March 2020 \\
Published: \\
31 May 2020 \\
\hline Keywords: \\
Creative Thinking \\
Skill, Metacognition, \\
CPS Learning Model
\end{tabular}

\begin{abstract}
Creative Problem Solving (CPS) learning model supports students to focus on learning and skill processes. CPS learning, students could select, process, and develop their responses in solving a problem creatively. Metacognition plays an important role in CPS since it could monitor students in selecting and using strategy to improve further cognitive performance. This research aims to find out effectiveness of CPS learning model on mathematics creative thinking skill reviewed from students' metacognitions. This mixed method research used sequential explanatory design. The population consisted of VIII graders at SMP N 4 Kudus. The samples consisted of experimental class with CPS learning and control class with discovery learning. The first stage of thr research was quantitative data collection. It were done using test and questionnaires to categorized the subject. The next stage was qualitative data collections which were done by using questionnaires and interview. Data of quantitative data were triangulated with the qualitative data to gain the goal of the research. The findings showed that CPS model was effective to improve creative thinking skill reviewed from students' metacognitions. Students with high metacognition in the experimental class are more creative than the control class. CPS learning can improve students' creative thinking through the stages of idea finding to acceptance finding, because students can find new ideas and choose the right solution from some of the ideas they have. Mathematics creative thinking skill of the students with high metacognition shown form the students' ability in writing problem solving skill of creative questions logically and could provide other notions. Students with medium category have the similar achievement but can correct errors; meanwhile students with low metacognition can wrote problem solving skill of creative questions quite logically and still have problems in giving ideas.
\end{abstract}

\footnotetext{
Correspondence address:

Jalan. A. Yani, Mendungan, Pabelan, Kec. Kartasura, Kabupaten

Sukoharjo, Jawa Tengah, Indonesia

p-ISSN 2252-6404

E-mail: khoirida17@gmail.com 


\section{INTRODUCTION}

Fostering national independence is an effort to develop a nation whom could solve each problem. Problem solving is a process to solve problems by using their owned knowledge. One of the required skills is creative thinking skill. Loewen et al. in Tsai (2013) explained that in learning mathematics, problem solving functions an important medium to share creative notion. Siswono (2011) argued that creativity is a product of creative thinking. Meanwhile, creative thinking is an activity which is directed to encourage or create creativity. Arvyati (2015) stated that an individual's creativity is on a capability to see connection between previous object and capability to create something new or provide new ideas which are applicable in solving problems. Thus, creativity is a thinking skill and act through personal problem solving idea. Lin (2017) explains that creative process is a resolution process of a problem from finding problem and executing problem solution.

According to Munandar, as quoted by Azhari \& Somakim (2013), there are four criteria of creative thinking skill. They are fluency, flexibility, originality, and elaboration. Guilford in Munandar (2014) argues that creativity or thinking creatively is a skill to involve various solution possibilities toward a problem in which it obtains less attention in educational world Florida (2015) shows from his research The Global Creativity Index 2015 as quoted in Martin Prosperity Institute explains that creativity criteria on technological, talent, and tolerance indicators, shows that Indonesia is in $115^{\text {th }}$ rank from 139 countries which became the sample of their research.

Based on the findings, mathematics creative thinking skill of Indonesian students are still low and need to be developed. Another finding which supports the result is students of VIII grade at SMP N 4 Kudus had difficulties in solving creative thinking skill problem on 3 Dimensions of geometry. The works of the students showed that they could not work on the tasks fluently. They only provided one alternative answer and their works were still unclear and incorrect.

Based on the students' works, its indicated that the students still had poor performance on answering creative thinking skill questions. From interview with the students, it also found that the students felt difficult in sharing other notions. It was due to the situation where they were not habituated to work on essay by providing more than one idea.

This lack capability of the students in creative thinking was also influenced by other aspects. One of them is metacognition owned by students. This lack of knowledge and control toward problems could cause delays in cognitive process of the students. Matlin (2013) argued that metacognition refers to science and selfcognition process control. Metacognition is important because knowledge about metacognition process could monitor us in selecting and using strategy to improve further cognitive performance.

Marzano (Pate and Miller, 2011) explains that metacognition will assist individuals in creating plan to reach their objectives, monitor, and control their mind. Iskandar (2014) states that metacognitive implementation process in learning will help students to have long lasting memory and understanding. In this research, the researcher tries to investigate metacognition student aspect in creative thinking to assist their long-term memories and understandings through metacognitive components.

Sperling et al. (2002) arranged metacognitive instrument called as Junior Metacognitive Awareness Inventory (Jr. MAI). The research measured child metacognition. Metacognition is divided into two components: (1) knowledge of cognition, referring to what is known by individuals about their own cognitions or about general cognition. This component covers three sub processes: declarative knowledge, procedural knowledge, and conditional knowledge; (2) regulation of cognition, on serial activities of assisting students to control their own learning and regulation of cognition covers four sub processes, such as planning, information 
management strategies, monitoring, and evaluation.

Besides metacognition aspect, one of supportive learning model to promote creative thinking is Creative Problem Solving (CPS) learning model. Shoimin (2014) states that CPS learning is a learning model focusing on teaching and problem solving skill of a question. That need to be considered in CPS learning is finding facts about the problem, finding ideas, and finding solutions with logical consideration. Students could promote problem solving skill to select and develop their responses. CPS model provides wider chances for students to express their creative ideas in solving a problem (Hariawan et al., 2014). Through CPS learning model, students could focus on teaching and skill processes, so they could select, process, and develop their responses in solving a problem.

The steps of the CPS learning model include (1) objective finding, (2) fact finding, (3) problem finding, (4) idea finding, (5) solution finding, and (6) acceptance finding. In the objective finding stage until problem finding, students learn to understand the problem and relate it to the knowledge they have. From the knowledge it has, at the stage of idea finding can bring up new ideas that can be applied. In the solution finding and acceptance finding stages, students can choose the best solution from the ideas discussed. Students' way of thinking starts to change to use new ways that are discussed together.

Based on the background, then the problems reviewed in this research are: (1) whether CPS learning model implementation is effective toward the students' mathematics creative thinking skills? And (2) How are the students' creative thinking skill reviewed from their metacognitions?

This research aims to find out effectiveness of CPS learning model on the students' mathematics creative thinking skills reviewed from their metacognitions. The benefit of this research is that it can provide ideas and new studies in learning for teachers to improve students' mathematical creative thinking skill. As well as can involve students to work with friends and communicate with teachers.

\section{METHOD}

The research population consisted of eighth graders of SMP N 4 Kudus, Kudus Municipality, with 192 students. Then the sample consisted of two classes. The experimental group was VIII A and the control group was VIII I. Each of the group consisted of 32 students. The experimental group was intervened by CPS learning model. Meanwhile, the control group was taught by Discovery Learning model. This mixed method research used sequential explanatory. The quantitative subjects used posttest only control and the qualitative research used purposive sampling technique. The qualitative subjects were taken from experimental class, with 7 students consisting of 2 high metacognition, 3 moderate metacognition, and 2 low metacognition students.

The data collection consisted of quantitative and qualitative data. The quantitative data was taken by using mathematics creative thinking skill test and questionnaire. The qualitative data collection was done by student metacognition questionnaire, mathematics creative thinking skill interview, and mathematics creative thinking skill test documentation. There were two data analysis. The quantitative data analysis consisted of normality, homogeneity, and variance similarity tests on Midterm test cores. On posttest, mathematics creative thinking skill consisted of normality, homogeneity, and hypothesis tests on posttest questions of mathematics creative thinking skill. The research hypothesis consists of mathematics creative thinking skill accomplishment test of experimental group with one right party t-test and mathematics creative thinking skill difference test by using t-test. Meanwhile, the qualitative analysis used triangulation techniques such as questionnaire, test, and interview. 


\section{RESULTS AND DISCUSSION}

1. Effectiveness of CPS learning model implementation toward Mathematics Creative Thinking Skill

1.a Initial Data

Based on initial data result of Midterm test for both groups, they covered normality, homogeneity, and variance similarity test. They were presented on Table 1.

Table 1. Inital Data Test Result

\begin{tabular}{llll}
\hline Test & Sig. & $\alpha$ & Criteria \\
\hline Normality & & 0.05 & \\
Experimental & 0.200 & & Normally \\
Control & 0.200 & & Distributed \\
Homogeneity & 0.188 & 0.05 & Homogeneous \\
Variance & 0.286 & 0.05 & Equal initial \\
Similarities & & & skills \\
\hline
\end{tabular}

On Table 1, it is known that the initial data of both student groups obtain sig score > 0.05 . Then, $\mathrm{H} 0$ is accepted. It means both groups are normally and homogeneously distributed as well as having same data variances. They also have same initial skills. After having initial data test, then the class could be intervened.

\section{1.b Posttest of Mathematics Creative Thinking Skill Questions}

Based on the posttest of mathematics creative thinking skill of both groups, before having hypothesis test, normality and homogeneity test were initially done to find out whether the hypothesis data used parametric or nonparametric test. The normality and homogeneity tests displayed on Table 2 .

Table 2. Posttest Results

\begin{tabular}{lccl}
\hline Test & Sig. & $\alpha$ & Criteria \\
\hline Normality & & & \\
Experimental & 0.200 & 0.05 & Normally \\
Control & 0.140 & & Distributed \\
Homogeneity & 0.144 & 0.05 & Homogeneous \\
\hline
\end{tabular}

On Table 2, it is known that posttest of mathematics creative thinking skill for both groups obtain Sig score $>0.05$. Thus, $\mathrm{H}_{0}$ is accepted. It means both groups were normally and homogeneously distributed or having same data variances.

After having normality and homogeneity test, hypothesis test could be carried out. The resutls of creative thinking skill accomplishment of experimental group by using one sample t-test as in Table 3.

Table 3. T-test Results of Experimental Group Accomplishment

Group Average $\begin{aligned} & \text { Sig. } \\
& \text { tailed) }\end{aligned}$
\begin{tabular}{lll} 
Experimental & 81.69 & Sig. \\
\hline & 0.000 & 0.05 \\
\hline
\end{tabular} On Table 3, it is obtained Sig (2-tailed) <
0.05 or $0.000<0.05$. Thus, $\mathrm{H}_{0}$ is denied. It
means mathematics creative thinking skill of
experimental group was higher than 71 (passing
the minimum criteria). Then, it was continued
by conducting hypothesis test, the varaince test
of the students' mathematics creative thinking
skills by using t-test as seen on Table 4.

Table 4. T-test Result of the Students' Mathematics Creative Thinking Skills

\begin{tabular}{lllll}
\hline Groups & Averages & $\begin{array}{l}\text { Sig. } \\
\text { tailed })\end{array}$ & $(2-$ & Sig. \\
\hline Experimental & 81.69 & 0.022 & 0.05 \\
Control & 74.53 & & \\
\hline
\end{tabular}

On Table 4, it is obtained $2 \times \operatorname{Sig}$ (2-tailed) $=2 \times 0.022=0.044<0.05$. Thus, $\mathrm{H}_{0}$ is denied. It means the average score of experimental group's mathematics creative thinking skill was higher than control group.

Based on hypothesis test, it shows that CPS model is effective toward mathematics creativet hinking skill. The learning effectiveness is the standard to determine the learning success. It is because learning in experimental group implemented new stages to think matheamtics creatively. Meanwhile, in Discovery Learning model, there was not stages to train students thinking creatively. This finding is in line with Asikin and Pujiadi (2008) whom proved that CPS was a dynamic approach. Students were more skillfull because they had more arranged 
internal procesure from the beginning. Then, this resaerch is supported by Ratnasari et al. (2019) whom explains that CPS model provides students to act like a scientist and to find their own knolwege. Then, this research is in line with Afriyani et al. (2014). She showed that CPS learning model could improve problem solving. Then, this research is in line with Busyairi et al. (2015). He explained that CPS learning model implementatin could improve cretive thinking skill significantly in solving problem than those taught by discovery learning.

\section{Mathematics Creative Thinking Reviewed from} Students' Metacognition

Based on the questionnaire result of experimental group students' metacognition, they had different mathematics creative thinking skills. The percentage of students' metacognition data could be seen on Table 5 .

Table 5. Percentage of the Students' Metacognition Data Categorization

\begin{tabular}{lllll}
\hline \multirow{2}{*}{ Metacognition } & \multicolumn{2}{l}{ Class } & Control & \\
\cline { 2 - 5 } & Experimental & & Student & Percentage (\%) \\
\cline { 2 - 5 } & Student Numbers & Percentage (\%) & Numbers & \\
\hline High & 9 & 28 & 7 & 25 \\
Moderate & 16 & 50 & 18 & 56 \\
Low & 7 & 22 & 7 & 22 \\
\hline Total & 32 & 100 & 32 & 100 \\
\hline
\end{tabular}

Based on the Table 5, it is known that the experimental class student metacognition questionnaire from high metacognition student obtains percentage $28 \%$ ( 9 students), moderate metacognition student obtains $50 \% \quad(16$ students), and low metacognition student obtains percentage $22 \%$ (7 students). While, control class student metacognition questionnaire from high metacognition student obtains percentage $25 \%$ (8 students), moderate metacognition student obtains $56 \% \quad$ (18 students), and low metacognition student obtains percentage $22 \%$ (7 students). It means that each group indicating to have different characteristics. It could be seen from the moderate group which had largest number.

After grouping, students from the experimental class were interviewed about mathematical creative thinking. The average accomplishment of mathematics creative thinking indicators, such as fluency, flexibility, originality, and elaboration on the representing subjects of each metacognition category on Figure 1.

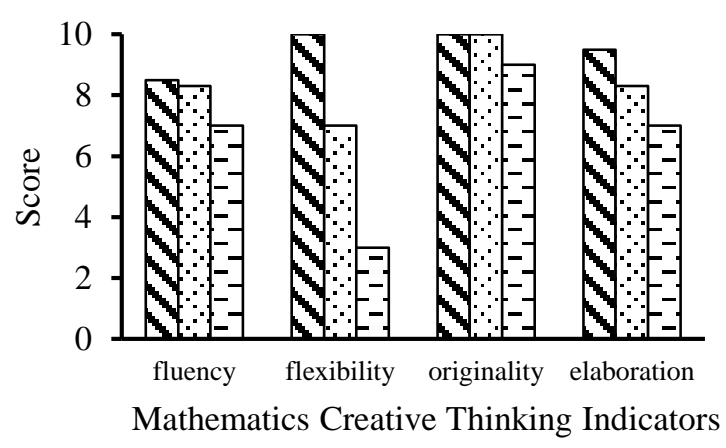

Figure 1. Average of Creative Thinking Indicator Achievement on Each Metacognition Remarks:

$\mathbf{D \nabla}=$ High metacognition subjects

$\therefore \therefore=$ Moderate metacognition subjects

E-_- $=$ Low metacognition subjects

Based on Figure 1, it shows that high metacognition subjects had higher achievement of creative thinking indicators than moderate and low categories as seen on each indicator. Here are the descriptions of the students' mathematics creative thinking skill on each student metacognition category.

2.a High Metacognition Category

According to Amin \& Mariani (2017) state metacognition is important in problem 
solving process. They are such as identification and understanding problems, re-revealing the problems by using their own language, planning problem solving process, and evaluating their skills based on the students' capabilities. Wahyudi (2016) explains that students with excellent metacognition could have better skills in solving problems. The students with high metacognition could answer creative thinking skill question clearly and correctly. The students with high metacognition wrote problem solving skill of creative questions logically and could provide other notions.

Subject 1 is a subject representing high metacognition group with high mathematics creative thinking skill test score. The posttest of subject 1 on high metacognition could be seen on Figure 2.

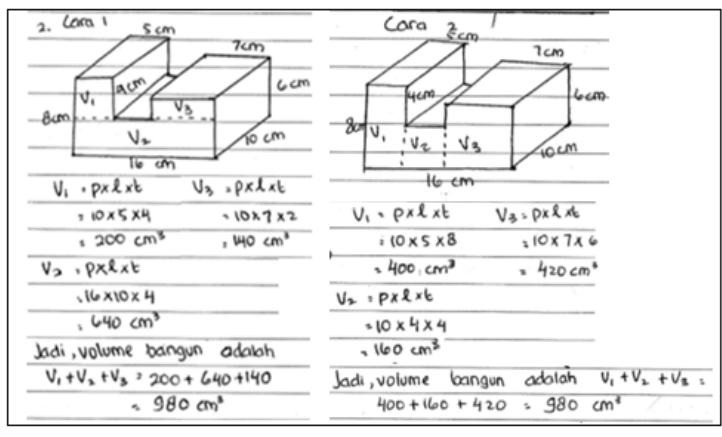

Figure 2. Posttest of High Metacognition

Figrue 1 shows that subject 1 could provide different ways betwen first alternative and 2 alternative answers. Both different alternatives which had different length, width, and heighth had accurate and correct answers.
To see whether subject 1 understood what he was writing, the subject was interviewed. From the interview, it was known that the subject could explain again the result from the beginning and could probide different alternatives to what he had written. It showed that the subject could work and explain again his answers on a question with excellent flexibility indicator.

On the student mathematics creative thinking indicator, high metacognition student met four creative thinking indicators, such as fluency, flexibility, originality, and elaboration excellent. It means the subjects had 4 level metacognition or very creative.

\section{2.b Moderate Metacognition}

Setyadi (2018) explains that metacognition allows students to adjust their actions into matheamtics problem solving process. However, sometime, there are hindrances experienced by students while working on the questions. The problems may unintentinally done and influence their works. Sudia's research (2015) showed that moderate metacognition students had involved plan and evaluation while solving problems. However, they did not involve re-checking so there were several mistakes.

Subject 2 is a subject representing moderate metacognition group with moderate mathematics creative thinking skill. The posttest results of subject 2 on moderate metacognition could be seen on Figure 3 .

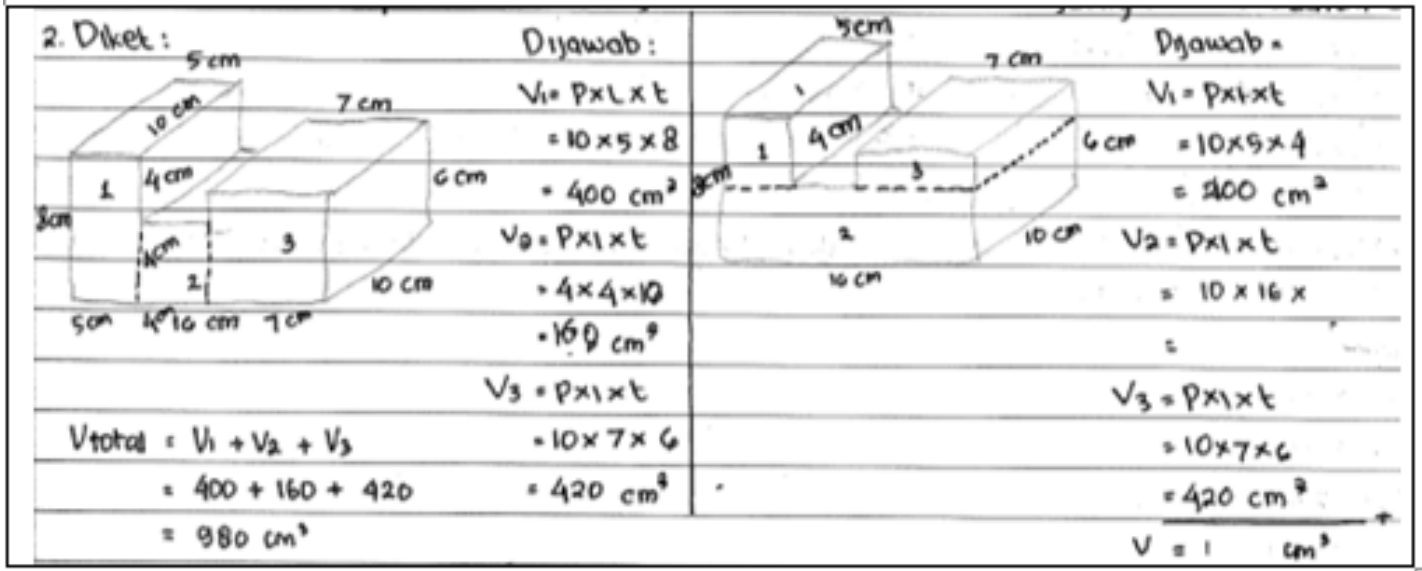

Figure 3. Posttest of Moderate Metacognition 
Figure 2 shows that subject 2 cold provide different ways betwen first alternative and second alternative answers. It is seen that subject 2 could provide 1 alternative answer correctly and accurately. However, the other alternative answers, the subject seemed to have not completed it. Thus, there was an empty on the last answer. To see whether subject 2 understood what he was writing, he was shown his own work. From the interview, the subject understood the mistakes and corrected it. Thus, the subjects could find same and accurate alternative answer 1 . It

showed that the subject could work, explain, and revise his mistake within flexibility indicator question sufficiently excellent.

The indicator achievement of student mathematics creative thinking skill showed that moderate metacognition student met three creative thinking indicators: fluency, flexibility, and originality excellently. Meanwhile, dealing with elaboration indicator, the subject had several hindrances. It means moderate metacognition subject is on level 3 , creative.

\section{Low Metacognition}

Sperling, Bruce, and Richard (2012) state students with low metacognition has less focused attention, recklessly learn manner, no planning to create, poor elaboration in his performance, no understanding while working. It is in line with Afinnas et al. (2018) stating that low metacognition stduents tend to be able to operate mathematics correctly. It is because the subject is not careful during promoting mathematics operation.

Subject 3 is a subject representing low metacognition with low mathematics creative thinking skill test score. The postest score of subject 3 with low metacognition could be seen on Figure 4.

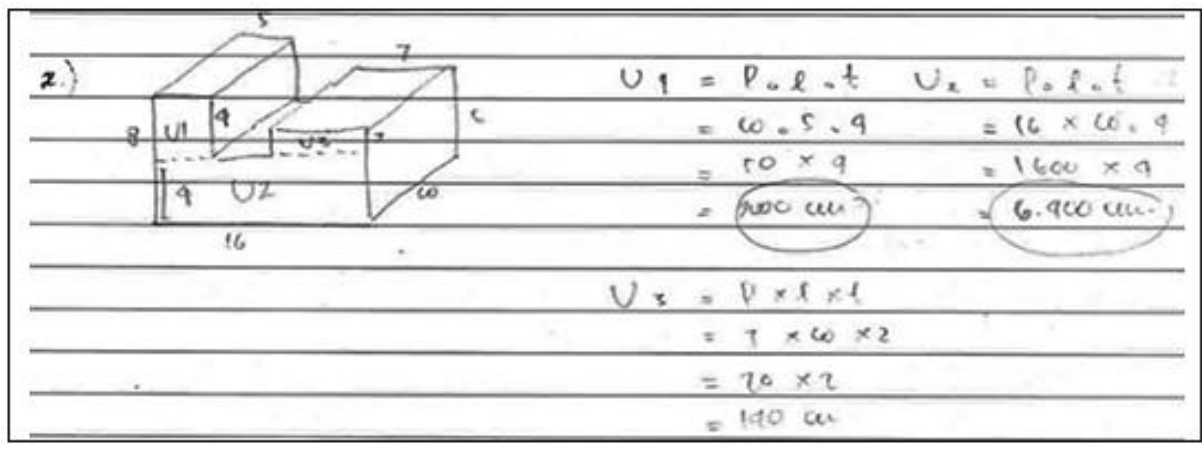

Figure 4. Posttest of Low Metacognition

Figure 4 shows that the subject could only provide one solution although it is not complete. The subject had counted each volume based on the size. However, the final results of volume 1 and 2 had miscalculation and the denominations were incorrect. It shows that the subject did not focus and was not careful in calculating the final results and the denomination. The subject was also seen to have not completed the problem by calculating those three volumes to get the total volume. So, the subject work was incorrect and inaccurate. To see whether the subject understood what he was writing, then an interview was carried out. From the interview, it was known that the subjects could explain again his work and he could revise their mistakes.
However, the subject still had difficulties in drawing and finding other alternative which could be used as new solution. It shows that the subject was still incapable in working and explaining question with flexibility indicator.

The indicator achievement of student mathematics creative thinking skill showed that low metacognition student met two creative thinking indicators: fluency and originality excellently. Meanwhile, dealing with flexibility and elaboration indicators, the subject had several hindrances. It means low metacognition subject is on level 2 , quite creative. 


\section{CONCLUSION}

Based on the result and discussion, it could be concluded that CPS learning model implementation was effective for mathematics creative thinking skill. It is shown by VIII graders' mathematics creative thinking skill taught by CPS could reach $75 \%$ classical accomplishment. The mathematics creative thinking skill of class taught by CPS was better than the conventional one. The high metacognition students had higher mathematics creative thinking skill achievements than moderate and low category studetns.

\section{ACKNOWLEDGMENT}

Thank to SMP N 4 Kudus for providing a place and facilities for research. Thanks to article writing reviewers whom have given advices and suggestions to improve this article writing and to assit its publication.

\section{REFERENCES}

Afinnas, F. T., Masrukan, M., \& Kurniasih, A. W. (2018). Analisis Kemampuan Penalaran Matematis Siswa dengan Model Self-Regulated Learning Menggunakan Asesmen Kinerja Ditinjau dari Metakognisi. PRISMA, Prosiding Seminar Nasional Matematika, 1, 197-207.

Afriyani, Chotim, \& Hidayah. (2014). Keefektifan Pembelajaran TTW dan SGW Berbantuan Kartu Soal Terhadap Kemampuan Pemecahan Masalah. Unnes Journal of Mathematics Education, 3(1), 4755.

Amin, Ihdi \& Mariani, Sc. (2017). PME Learning Model : The Conceptual Theoretical Study of Metacognition Learning In Mathematics Problem Solving Based On Constructivism. IEJME - Mathematics Education, 12(4), 333-352.

Arvyati., M I \& Andry I. 2015. Effectivity of Peer Tutoring Learning to Increase Mathematical Creative Thinking Ability of Class XI IPA SMAN 3 Kendari 2014.
International Journal of Education and Research, 3(1), 613-628.

Asikin \& Pujiadi. (2008). Pengaruh Model Pembelajaran Matematika Creative Problem Solving (CPS) Berbantuan CD Interaktif Terhadap Kemampuan Pemecahan Masalah Pada Siswa SMA Kelas X. Lembaran Ilmu Kependidikan, 37 (1), 37-45.

Azhari \& Somakim. (2013). Peningkatan Kemampuan Berpikir Kreatif Matematik Siswa Melalui Pendekatan Konstruktivisme di Kelas VII Sekolah Menengah Pertama (SMP) Negeri 2 Banyuasin III. Jurnal Pendidikan Matematika, 7(2), 1-12.

Busyairi. (2015). Strategi Pembelajaran Creative

Problem Solving (CPS) Berbasis Eksperimen untuk Meningkatkan Kemampuan Kognitif dan Keterampilan Berpikir Kreatif. Jurnal Pengajaran MIPA, 20(2), 133-143.

Florida, R M C \& King, K. 2015. "The Global Creativity Index 2015". Toronto: Martin Prosperity Institute.

Hariawan., Kamaluddin., \& Wahyono, U. (2014). Pengaruh Model Pembelajaran Creative Problem Solving Terhadap Kemampuan Memecahkan Masalah Fisika pada Siswa Kelas XI SMA Negeri 4 Palu. Jurnal Pendidikan Fisika Tadulako, 1(2), 48-54.

Iskandar, S. M. (2014). Pendekatan Keterampilan Metakognitif dalam Pembelajaran Sains di Kelas. ERUDIO, 2(2), 13-20.

Lin, C Y. (2017). Threshold Effects of Creative Problem Solving Attributes on Creativity in the Math Ability of Taiwanese Upper Elementary School. Hindawi Education Research International 2017, Article ID 457138, 1-9.

Matlin \& Geneseo. (2013). Cognition Eighth Edition. America: Wiley.

Munandar, U. (2014). Pengembangan Kreativitas Anak Berbakat. Jakarta: Rineka Cipta.

Pate \& Miller. (2011). Effects to Think-Aloud Pair Problem Solving on Secondary-Level 
Students, Performance in Career and Technical Education Courses. Journal of Agricultural Education, 1(52), 120-131.

Ratnasari, Suciati, \& Maridi. (2019). Empowering Scientific Thinking Skills Through Creative Problem Solving with Scaffolding Learning. Jurnal Pendidikan Biologi Indonesia, 5(1). 61-68.

Setyadi. (2018). Proses Metakognisi Mahasiswa dalam Memecahkan Masalah Matematika (Studi Kasus pada Mahasiswa Pendidikan Matematika UKSW). Kreano 9(1), 93-99.

Shoimin, A. (2014). 68 Model Pembelajaran Inovatif dalam Kurikulum 2013. Yogyakarta: Ar-Ruzz Media.

Siswono, T Y E. (2011). Level of Students Creative Thinking in Classroom Mathematics. Journal Education Reseach and Review, 6(7), 548-553.
Sperling, Howard, Miller, \& Murphy. (2002). Measures of Children's Knowledge and Regulation of Cognition. Contemporary Educational Psychology, 27, 51-79.

Sudio. (2015). Profil Metakognisi Siswa SMP dalam Memecahkan Masalah Open Ended Ditinjau dari Tingkat Kemampuan Siswa. Jurnal Math Educator Nusantara, 1(1), 29-40.

Tsai, K C \& Mattew S. (2013). Exploratory Examination of Relationships Between Learning Styles and Creative Thinking in Math Students. International Journal of Academic Research in Business and Social Sciences, 3(8), 506-519.

Wahyuddin. (2016). Pengaruh Metakognisi, Motivasi Belajar, dan Kreativitas Belajar Terhadap Kemampuan Pemecahan Masalah Siswa Kelas VIII SMP Negeri 2 Sabbangparu Kabupaten Wajo. Jurnal Inovasi Pendidikan Matematika, 4(1), 72-83. 